\title{
Development of Comprehensive General Nutrition and Nutrition Label Questionnaire
}

\author{
Galuh Nita Prameswari ${ }^{1}$, Arif Rahmat Kurnia ${ }^{2}$, Awalukin Arianto ${ }^{3}$, Tsaniatin Nahla ${ }^{4}$, Mila \\ Aliffia $^{5}$ \\ \{nitagisela@mail.unnes.ac.id ${ }^{1}$, arifrk@mail.unnes.ac.id ${ }^{2}$, aaawalukin@gmail.com ${ }^{3}$ \} \\ Universitas Negeri Semarang, Semarang, Indonesia ${ }^{1,2,3,4,5}$
}

\begin{abstract}
This research to develop an instrument to measure the knowledge and habit related to general nutrition and nutrition labels with good validity and reliability. The Comprehensive General Nutrition and Nutrition Label Questionnaire (CGN2LQ) were developed in Bahasa by modifying its content to suit the latest trend in nutrition education. The questionnaire tested on 67 adolescent students (universities and high school) in Semarang, Indonesia. The Cronbach's alpha for validity and alpha value for reliability was used. There were seven section of the questionnaire with total 132 questions. The result showed that 62 questions were valid for the final version of CGN2LQ. The questionnaire were reliable. The validity by scoring consistently more than 0.2404 which is $0.241-0.909$ on each section. The reliability shown high alpha ranging from 0.686 to 0.974 . The CGN2LQ meets the criteria for validity and reliability. The CGN2LQ useful to understand the relationship between nutrition knowledge, nutrition labels knowledge and habit of nutrition labels use.
\end{abstract}

Keywords: nutrition labels, nutrition knowledges, nutrition label habits, nutrition labels questionnaire, nutrition knowledges questionnaire.

\section{Introduction}

Nutrition knowledge is something that is known about food in relation to optimal health. Nutrition knowledge includes knowledge about selection and daily consumption properly and provides all the nutrients needed for normal functioning of the body. Nutrition knowledge has an important role in determining a person's nutritional status. Good nutritional knowledge can make someone more careful so that they will have the type of food consumed better. Low knowledge of a person's nutrition is associated with poor nutritional status such as malnutrition or over nutrition. This is because people who have low nutritional knowledge tend to consume foods that are high in sugar, high in fat, high in salt, and low in fiber [1]. Various innovations have been made to improve nutritional knowledge, but nothing has been applied nationally except by the use of nutritional information labels on packaged food products [2,3].

Nutrition label is an obligation which is imposed on producers to provide nutritional product information on packaging [4,5]. The component of nutrition information label that is most often read is the label about fat information, while the least read is sodium [3]. The 
gender and attitude of students are related to the behavior of reading nutrition information labels [6].

The level of education is related to the habit of reading nutrition information labels. The behavior of reading nutrition labels relates to the level of education, people who have higher education and come from urban areas tend to read nutrition information labels more often [7]. Too much information on nutrition labels can hamper understanding, when the information is sufficient, understanding and use will be better [8]. Good nutritional knowledge will make people tend to read and pay attention to nutritional information labels, so that it will affect the choice of food products purchased $[9,10]$. This research aimed to develop a valid and reliable questionnaire to measure nutrition knowledge, nutrition labels knowledge, and the habit of nutrition labels use.

\section{Methods}

This study was descriptive observational using cross sectional design. The questionnaires was developed first by combining several questionnaires and adding relevant items for improving the validity and reliability[11,12]. Data is collected using online questionnaires through Google Form and distributed via email and WA because the research location is experiencing RCA (Restricted Community Activities). The study was not included in clinical research, and no intervention was carried out on the subject. Informed Consent information and research procedures are given directly to subjects during the data collection process. Recruitment of subjects is done through WA groups, private WA, and e-mail. The data entered will never be opened to the public, and there is no possibility of further use of the personal data collected.

The number of questions contained in the questionnaire was 98 items.Quantitative data retrieval is done by using online questionnaire. Data collected are primary and secondary data. Primary data were obtained from respondents' answers from questionnaires that included sample identity, nutritional knowledge, and the use of nutritional information labels. Whereas secondary data was obtained from the Central Statistics Agency of Semarang. The research instrument used was the CGN2LQ.

The instrument validity and reliability tests were carried out on teenagers in Semarang city at least 30 people. So that the questionnaire was truly understood by the research subjects and could measure what would be measured (valid) and provide consistent (reliable) results.

\section{$3 \quad$ Results and discussions}

In Table 1 it can be seen that the age of respondents is mostly 19 years (64.2\%). And most of them are female respondents $(85.1 \%)$. Most respondents have a higher education background $(86.6 \%)$. More than half of the respondents $(55.2 \%)$ are currently undergoing nutrition education. And there is one respondent who smokes $(1.5 \%)$

Government Regulation Number 69 of 1999 concerning Food Labels and Advertising states that the inclusion of nutritional content on labels must be done for packaged food accompanied by a statement that food contains vitamins, minerals and other nutrients added and food required under statutory regulations [13]. This food labeling aims to provide true and 
clear information to the public about packaged food products before buying or consuming them [14].

Many factors play a role in influencing someone to use food labels, including nutrition education [15]. Someone who has healthy eating habits is also more likely to use nutritional value information [15].

Based on the results of research [16] nutrients that are often the attention of respondents in reading information on the nutritional value of packaged foods are $49.5 \%$ fat, $41.5 \%$ saturated fat, and only $24.1 \%$ who pay attention to sodium content. Respondents with an average age of $>20$ years will pay more attention to the nutritional content of protein, vitamins, fat and sugar on the packaging and never or rarely pay attention to the content of sodium, dietary fiber, and cholesterol [13]. As for the reasons of respondents who do not read the label most packaged food product nutrition states do not understand or understand, not enough time to read and do not feel important [16]. The percentage of men is less concerned with food labels [16].

Table 1. Characteristics of the respondents

\begin{tabular}{lccc}
\hline \multicolumn{1}{c}{ Characteristics } & Parameter & $\mathrm{N}=67$ & $\%$ \\
\hline Age & 16 & 3 & 4.5 \\
& 17 & 5 & 7.5 \\
& 18 & 16 & 23.9 \\
\multirow{3}{*}{ Gender } & 19 & 43 & 64.2 \\
& Boy & 10 & 14.9 \\
Education & Girl & 57 & 85.1 \\
& High School & 9 & 13.4 \\
Nutrition's study & University & 58 & 86.6 \\
\multirow{2}{*}{ Smoking } & Yes & 37 & 55.2 \\
& No & 30 & 44.8 \\
& Yes & 1 & 1.5 \\
& No & 66 & 98.5 \\
\hline
\end{tabular}

There were seven section of the questionnaire with total 132 questions. The result showed that 62 questions were valid for the final version of CGN2LQ, and this questionnaire were reliable. The validity by scoring consistently more than 0.2404 ( $\mathrm{r}$ table for 67 samples) which is 0.241-0.909 on each section. The reliability shown high alpha ranging from 0.686 to 0.974. 
Table 2. Results of comprehensive validity and reliability tests of General Nutrition and Nutrition Label Questionnaire (CGN2LQ) ( $\mathrm{r}$ table in 67 samples are 0.2404)

\begin{tabular}{llcc}
\hline CGN2LQ & \multicolumn{1}{c}{ Part Names } & $\begin{array}{c}\text { Correlation } \\
\text { coefficient } \\
\text { value }\end{array}$ & Reliability \\
\hline Section 1 & Nutrition Advice & $0.390-0.495$ & 0.703 \\
Section 2 & Food Classification & $0.262-0.477$ & 0.716 \\
Section 3 & Food Choice & $0.280-0.714$ & 0.686 \\
Section 4 & Nutrition and Diseases & $0.280-0.714$ & 0.686 \\
Section 5 & Nutrition Label Knowledge & $0.241-0.700$ & 0.815 \\
Section 6 & Nutrition Label Use & $0.604-0.909$ & 0.974 \\
Section 7 & Nutrition Label Habits & $0.491-0.610$ & 0.774 \\
\hline
\end{tabular}

The validity and reliability of the questionnaires is pretty good. The questionnaire itself run into some robust editing process. The 132 questions from the first version of the CGN2LQ is only divided into two sections, a nutrition knowledge section and a nutrition label section. The researcher found the questioner was too much, so it decided to divide it into smaller sections. After doing discussion with adolescents in Department of Nutrition, it was decided to divide the section into 7 which were nutrition advice, food classification, food choice, nutrition and diseases, nutrition label knowledge, nutrition label use, and nutrition label habits. The questionnaires then made into google form versions, which then distributed to the students both in high schools and universities. From 67 respondents, we conduct validity and reliability tests. These tests proved that some questions were invalids, so we decided to put down those invalid questions. There are a number of items that are invalid questions, including questions that answer respondents' answers that are almost the same (similar), so that the validity is low. For example, questions related to consumption of sweet foods (containing added sugar), show the results that almost all respondents stated that consumption of sweet foods and drinks (containing added sugar) must be limited. Questions related to foods and beverages that are usually low in added sugar are natural yogurt, most respondents also stated a similar answer to the question item that ice cream contains a lot of added sugar, most respondents also stated the same answer when responding to questions about canned foods containing high salt. Some items that get answers almost all the same question related to oats containing high fiber, most respondents also answered correctly that poultry such as chicken, duck, turkey, are good food sources of protein, including beans as a source of protein. Likewise with food sources of carbohydrates, all respondents stated that potatoes or tubers are a good source of carbohydrates. In the related section of diseases related to nutritional intake, several questions that almost all respondents answered were similar namely that diseases related to low intake fiber in food is a large intestine disorder, it is possible that some of the questions they have got in the material provided at school are related to the nutrient content in food and some diseases related to food intake. Many question items with true or false answer types, show invalid results. There are also several question items that are related to the same thing but with different question item numbers with different sentences. Furthermore, the question items that were invalid were excluded from the questionnaire, because they were already represented by other question items with the same material topic even with different sentences.At the end there were 62 valid and reliable questions which divided into 7 sections.

The reliability test is ranging from 0.686 to 0.974 . The validity itself made this questionnaire is good to be used as tools in measuring knowledge and habits in nutrition 
knowledges and nutrition habits. This questionnaire is important tool in measuring nutrition label knowledge and habit. Those two were important factors in enabling the use of nutrition label in later stage of life [13]. Nutrition label is prominence in improving awareness about the food quality. Good nutrition label will be understandable across multiple circumstances ranging from different economic status, different educational background, and even in the different geographical areas[7]. The impact alone is far greater than another education tools such as poster, leaflet, pamphlet, or booklet, because nutrition label is arbitrary in all processed foods[14]. So, the role it plays is very important one.

\section{Conclusion}

This research demonstrated that the CGN2LQ meets the criteria for validity and reliability. It should be useful to understand the relationship between nutrition knowledge, nutrition labels knowledge and habit of nutrition labels use.

\section{Acknowledgements}

This research is funded by Dana PNBP DIPA FIK UNNES 2020. Author declares that there is no conflict of interest regarding the publication of this articles.

\section{References}

[1] Sartika RAD. Pengaruh Pendidikan Gizi terhadap Pengetahuan dan Perilaku Konsumsi Serat pada Siswa. J Ilmu Pendidik. 2011;17(4):322-30.

[2] Wulandari M, Prameswari GN. Media Komik terhadap Peningkatan Pengetahuan dan Sikap Gizi pada Anak yang Gemuk dan Obesitas. J Health Edu. 2017;2(1):73-9.

[3] Sudahono N, Indrawani YM. Gambaran Perilaku Membaca Label Pangan Dan Reguler Fakultas Kesehatan Masyarakat Universitas Indonesia Angkatan 2013. Universitas Indonesia; 2014.

[4] Kustantinah. Peraturan Kepala Badan Pengawas Obat dan Makanan Republik Indonesia tentang Pengawasan Klaim dalam Label dan Iklan Pangan Olahan. Jakarta: Badan Pengawas Obat dan Makanan; 2011 p. 1-46.

[5] Kementerian Kesehatan RI. Pedoman Gizi Seimbang (Pedoman Teknis Bagi Petugas dalam Memberikan Penyuluhan Gizi Seimbang). Direktorat Jenderal Bina Gizi dan Kesehatan Ibu dan Anak, editor. Jakarta: Kementerian Kesehatan RI; 2014. 129 p.

[6] Sinaga C, Simanungkalit SF. Faktor-Faktor yang Berhubungan dengan Perilaku Membaca Label Informasi Gizi. J Endur. 2019;4(1):192.

[7] Mandle J, Tugendhaft A, Michalow J, Hofman K. Nutrition labelling: A review of research on consumer and industry response in the global South. Glob Health Action. 2015;8(1):1-10.

[8] Nørgaard MK, Brunsø K. Families' use of nutritional information on food labels. Food Qual Prefer [Internet]. 2009;20(8):597-606. Available from: http://dx.doi.org/10.1016/j.foodqual.2009.07.005

[9] Brunner TA, van der Horst K, Siegrist M. Convenience food products. Drivers for consumption. Appetite [Internet]. $2010 \quad$ Dec;55(3):498-506. Available from: http://dx.doi.org/10.1016/j.appet.2010.08.017

[10] Kakinami L, Houle-Johnson S, McGrath JJ. Parental Nutrition Knowledge Rather Than Nutrition Label Use Is Associated With Adiposity in Children. J Nutr Educ Behav. 2016;48(7):461-467.e1.

[11] Kliemann N, Wardle J, Johnson F, Croker H. Reliability and validity of a revised version of the General Nutrition Knowledge Questionnaire. Eur J Clin Nutr. 2016;70(10):1174-80. 
[12] Alsaddah AS. How Does Knowledge and Utilization of Nutrition Labels. Kent State University; 2014.

[13] Cassady DL. Food Label Knowledge. Appetite. 2015;207-16.

[14] BPOM. Pengawasan Klaim dalam Label dan Iklan Pangan Olahan. Jakarta, Indonesia; 2011. n food label use. A Rev Lit. 2015;92:207-16.

[15] Campos S, Doxey J, Hammond D. Nutrition labels on pre-packaged foods: A systematic review. Public Heal Nutr. 2011;14:1496-506.

[16] Castillo L, Moya. Information search behaviour, understanding and use of nutrition labeling by residents of Madrid, Spain. J Public Heal. 2015;129(3):226-36. 